\title{
ANALISIS YURIDIS PERLINDUNGAN HUKUM TENAGA MIGRAN KORBAN PERDAGANGAN MANUSIA OLEH PEMERINTAH INDONESIA
}

\author{
Safrida Yusitarani ${ }^{*}$, Nabitatus Sa'adah ${ }^{2}$ \\ 1Program Studi Magister Ilmu Hukum, Fakultas Hukum, Universitas Diponegoro \\ ${ }^{2}$ Fakultas Hukum, Universitas Diponegoro \\ Safrida21@ gmail.com
}

\begin{abstract}
Indonesian migrant workers make a major contribution to the Indonesian economy. Given that Indonesia is the country of origin of the second largest migrant workers in ASEAN. Various regulations have been made as a form of protection by the Indonesian government. But there are still many problems that arise, among them is human trafficking. The research method in this article is normative juridical by using the statutory approach (statue approach) and conceptual approach (conceptual approach). The data used in this writing are secondary data, namely library books, laws and regulations, scientific work, articles, and documents relating to research material. Government efforts to eradicate trafficking of Indonesian workers include the issuance of various legal instruments, bilateral, regional and multilateral cooperation, particularly in the destination countries for the placement of migrant workers, and in cooperation with non-governmental institutions. Government efforts in providing legal protection to migrant workers who are victims of trafficking are through the provision of restitution and compensation, counseling services and medical services or assistance, legal assistance and providing information as well as ensuring the fulfillment of the rights of migrant workers victims of human trafficking, such as confidentiality of identity to the right to rehabilitation .
\end{abstract}

\section{Keywords: Legal Protection; Migrant Workers; Human Trafficking.}

\begin{abstract}
ABSTRAK
Pekerja migran Indonesia memberikan kontribusi besar terhadap perekonomian Indonesia. Mengingat Indonesia merupakan negara asal pekerja migran kedua terbesar se-ASEAN. Berbagai peraturan telah dibuat sebagai bentuk upaya perlindungan oleh pemerintah Indonesia. Namun masih banyak ditemukan masalah yang muncul, diantarnaya adalah perdagangan manusia. Metode penelitian dalam artikel ini yaitu yuridis normatif dengan menggunakan pendekatan undang-undang (statue approach) dan pendeketan konseptual (conceptual approach). Data yang digunakan dalam penulisan ini adalah data sekunder, yaitu buku-buku perpustakaan, peraturan perundang-udangan, karya ilmiah, artikel-artikel, serta dokumen yang berkaitan dengan materi penelitian. Upaya pemerintah memberantas perdagangan manusia terhadap tenaga kerja Indonesia antara lain mengeluarkan berbagai instrumen hukum, melakukan kerjasama bilateral, regional, maupun multilateral terutama negara tujuan penempatan TKI, dan bekerja sama dengan lembaga non pemerintahan. Upaya pemerintah dalam memberikan perlindungan hukum kepada TKI korban perdagangan manusia adalah dengan pemberian restitusi dan kompensasi, layanan konseling dan pelayanan atau bantuan medis, bantuan hukum dan pemberian informasi serta menjamin pemenuhan hak-hak TKI korban perdagangan manusia, seperti kerahasian identitas hingga hak untuk mendapatkan rehabilitasi.
\end{abstract}

\section{Kata kunci: Perlindungan Hukum; Tenaga Migran; Perdagangan Manusia.}

\footnotetext{
* Corresponding Author
} 


\section{A. PENDAHULUAN}

Indonesia adalah salah satu negara dengan jumlah penduduk terbesar di dunia. Pada tahun 2019, jumlah penduduk Indonesia terhitung berjumlah 267 juta jiwa. Berdasarkan data Laporan Pekerja Global Indonesia, pada 2016, jumlah pekerja migran Indonesia yang bekerja di luar negeri tercatat lebih dari 9 juta orang dengan 3/4 diantaranya merupakan pekerja berketerampilan rendah. Dari 9 juta pekerja migran tersebut sekitar $32 \%$ bekerja sebagai pembantu rumah tangga atau pengasuh anak, pekerja pertanian 19\%, pekerja konstruksi $18 \%$, pekerja pabrik 8\%, perawat lansia $6 \%$, pekerja toko/restoran/hotel, supir $2 \%$, dan $0,5 \%$ pekerja kapal pesiar. Meskipun kejahatan ini sudah berlangsung cukup lama, namun dalam prakteknya terus berkembang luas mengikuti perkembangan teknologi. Kejahatan ini mengalami transformasi model, bentuk, cara-cara terstruktur dan sistematis menuju pola-pola eksploitasi manusia (Daniell, Mulyana, \& Wibhawa, 2018).

Tenaga Kerja Indonesia (selanjutnya disebut TKI) memberikan dampak dan kontribusi yang besar untuk perekonomian negara, namun banyak masalah-masalah yang muncul dari pengiriman tenaga kerja migran ini (Susetyorini, 2010). Pemerintah Indonesia dianggap telah gagal dalam memberikan perlindungan dan memberikan mereka hak asasi manusia yang mendasar (Djelantik, 2016).

Perdagangan manusia merupakan tindakan yang tidak berperikemanusiaan terhadap harkat dan martabat manusia. Korban tidak saja diperdagangkan untuk eksploitasi seksual dan pelacuran tapi juga kerja paksa dan perbudakan. Pelaku perdagangan orang biasanya menjadikan komunitas rentan untuk dijadikan korban, yakni perempuan dan anak-anak (Winterdyk, \& Reichel, 2010). Berdasarkan United Nations Office on Drugs and Crime (selanjutnya disebut UNODOC), sebuah organisasi di bawah PBB yang berfokus pada masalah perdagangan dan penggunaan narkoba secara ilegal, pencegahan kejahatan dan keadilan kriminal, terorisme internasional dan korupsi politik, sekitar 49\% dari korban tindak perdagangan manusia adalah wanita, 21\% anak-anak perempuan, 18\% pria, dan 12\% adalah anak laki-laki. Wanita merupakan korban terbanyak dari tindak pidana perdagangan orang melalui pengiriman tenaga migran ini. Dalam kasus di mana anak-anak menjadi korban, perdagangan biasanya dilakukan untuk memberkan keuntungan kepada kerabat atau keluarga mereka. Beberapa orang tua mungkin secara tidak sadar memperdagangkan anak-anak mereka sendiri terutama ketika mereka menyadari dalam situasi di mana pendapatan mereka tidak dapat memenuhi kebutuhan hidup sehari-hari. Selain untuk memenuhi kebutuhan dasar, mereka juga diperkejakan untuk melunasi hutang agar mendapat uang dengan cepat dan mudah (Oppong, 2012). Untuk menjelaskan mengapa buruh migran cenderung dikaitkan dengan pekerjaan berkualitas rendah, perlu lagi diperiksa dari sisi penawaran, sisi permintaan dan faktor yang terkait dengan kebijakan dan lembaga (Wright, \& Clibborn, 2019). 
Banyak faktor yang memengaruhi masih tinggi nya angka pedagangan manusia. Pembangunan yang tidak merata menyebabkan kemiskinan sebagai penyebab utama perdagangan manusia. Pembangunan yang tidak merata terjadi karena modal lebih terkonsentrasi di daerah di mana investor dapat menghasilkan keuntungan, yaitu daerah-daerah yang memiliki sumber daya manusia yang berkualitas, infrastruktur transportasi wilayah dan komunikasi yang baik. Akibatnya, beberapa bagian daerah mengalami kekurangan lapangan kerja (Shelley, 2010). Persoalan kemiskinan yang tidak kunjung selesai, membuat masyarakat tidak punya banyak pilihan untuk menyambung hidupnya. Dalam posisi yang serba sulit inilah, sekali lagi perempuan menjadi pihak yang dirugikan. Persentase tenaga kerja wanita selalu lebih besar daripada tenaga kerja laki-laki yang berangkat ke luar negeri (Muflichah, \& Rahadi, 2009). Ada juga faktor yang berasal dari luar korban, yaitu budaya masyarakat yang belum mengenal kesetaraan gender, lemahnya sistem hukum Indonesia dan kondisi daerah yang tidak mendukung (Nuraeny, 2011).

Persoalan kemiskinan yang terus berlanjut membuat masyarakat banyak yang ingin bekerja di luar negeri melalui jalur yang cepat dan mudah. Namun sayangnya, hal ini menyebabkan mereka menjadi korban perdagangan manusia karena tidak melalui prosedur sesuai aturan hukum yang berlaku. Pengalaman eksploitatif juga sering dialami oleh pekerja migran tidak berdokumen. Ada dua penyebab utama pekerja migran tidak berdokumen. Pertama adalah melalui migrasi ilegal, kebanyakan dari mereka adalah orang miskin yang tidak mampu membayar biaya migrasi yang mahal apabila melalui proses hukum yang resmi. Kedua, pekerja legal yang melarikan diri dari majikan mereka karena majikan mereka menahan semua dokumen mereka (Absor, 2018). Banyaknya pekerja migran Indonesia yang menjadi korban perdagangan manusia inilah yang menarik untuk dikaji terkait dengan perlindungan pemerintah terhadap pekerja migran yang menjadi korban perdagangan manusia ini.

Teori menempati kedudukan yang penting, hal demikian dikarenakan teori memberikan sarana untuk dapat menerangkan serta memahami masalah yang dibicarakan secara lebih baik. Hal-hal ini yang semula tampak tersebar dan berdiri sendiri dapat disatukan dan ditunjukkan kaitannya satu sama lain secara lebih bermakna (Dimyati, 2010). Berikut teori yang penulis gunakan untuk menganalisis permasalahan ini, yakni teori bekerjanya hukum di masyarakat. Teori bekerjanya hukum di masyarakat dari Robert B. Seidman terdapat tiga komponen yang dapat dijelaskan. Ketiga komponen tersebut meliputi : (a) Lembaga pembuat peraturan, (b) Lembaga penerap peraturan, (c) Pemegang peran. Setiap peraturan hukum memberitahu tentang bagaimana seorang pemegang peran (role occupant) diharapkan bertindak. Bagaimana seseorang pemegang peran itu akan bertindak sebagai respon terhadap peraturan hukum yang merupakan fungsi peraturan-peraturan yang ditujukan kepadanya, sanksi-sanksinya, aktivitas 
dari lembaga-lembaga pelaksana serta keseluruhan kompleks kekuatan sosial, politik, dan lain-lainnya. Bagaimana lembaga-lembaga pelaksana itu akan bertindak sebagai respon terhadap peraturan peraturan hukum, merupakan fungsi peraturan hukum yang ditujukan kepada mereka, sanksi sanksinya, keseluruhan kompleks kekuatan kekuatan sosial, politik dan lain-lainnya yang mengenai diri mereka serta umpan balik yang datang dari pemegang peran. Bagaimana para pembuat undang-undang itu akan bertindak merupakan fungsi-fungsi peraturan-peraturan yang mengatur tingkah laku mereka, sanksi-sanksi, keseluruhan kompleks kekuatan-kekuatan sosial, politik, ideologi dan lainnya yang mengenai diri mereka serta umpan balik yang datang dari pemegang peran serta birokrasi (Rahardjo, 1986).

Berdasarkan pendahululan di atas maka dapat dilihat ada nya kesenjangan dari peraturan yang sudah ada dengan apa yang terjadi dilapangan. Peraturan mengenai perlindungan perdagangan manusia sudah banyak diatur dalam hukum nasional Indonesia, namun dalam fakta di lapangannya, masih banyak tindak kejahatan perdagangan orang dengan korban tenaga migran yang dikirim ke luar negeri. Maka rumusan masalah dalam Penelitian ini, adalah sebagai berikut: (1) Bagaimana upaya pemerintah memberantas perdagangan manusia terhadap TKI?, (2) Bagaimana perlindungan hukum yang diberikan terhadap TKI korban perdagangan manusia?
Dalam penelitian ini menggunakan referensi penelitian sebelumnya yang dilakukan oleh beberapa peneliti yang membahas mengenai upaya pemberantasan perdagangan orang dan perlindungan hukum terhadap korbannya. Hasil penelitian sebelumnya akan digunakan untuk mendukung penelitian ini yakni sebagai berikut: penelitian Dhani Akbar membahas bentuk pengawasan pemerintah daerah dalam mencegah dan menanggulangi perdagangan manusia di Kabupaten Karimun dan Kota Batam serta bagaiamana Tinjauan Hukum perdagangan manusia di Kabupaten Karimun dan Kota Batam ( Akbar, 2018)

Dalam penelitian Mohammad Fadil dibahas mengenai pengaturan hukum internasional tentang larangan perdagangan perempuan dan implementasi hukum internasional di Indonesia. Penelitian ini fokus pada peraturan tertulis yang ada dan bagaimana pengimplementasiannya (Fadil, 2013). Penelitian oleh Abdul Rahman Prakosa dan Putri Ayu Nurmalinda membahas mengenai ruang lingkup tindak pidana perdagangan orang dan indikator penyebab dan akibat bagi korban serta implementasi atas kebijakan hukum pencegahan perdagangan orang. Penelitian ini berbeda dengan apa yang diteliti penulis dalam tulisan ini karena penulis fokus terhadap pencegahan dan perlindungan hukum yang diberikan kepada korban (Prakoso \& Nurmalinda, 2018).

Dalam penelitian yang dilakukan oleh Won Kidane, peneliti lebih berfokus pada pemahaman dari perdangan orang dan korban-korbannya itu sendiri. Bagaiamana definisi perdagangan orang dan 
kaitannya dengan eksploitasi seksual terhadap wanita dan bagaiaman efek selanjutnya terhadap korban (Kidane, 2011). Penelitian yang dilakukan oleh John Winterdyk dan Philip Reichel, membahas mengenai overview dan bersifat lebih umum, deskriptif, teoritikal dan isu praktis dari tindak perdagangan manusia serta peran dari negara transit dalam tindak pindana perdagangan orang (Winterdyk, \& Reichel, 2010).

\section{B. METODE PENELITIAN}

Metode penelitian dalam artikel ini yaitu yuridis normatif dengan menggunakan pendekatan undang-undang (statue approach) dan pendekatan konseptual (conceptual approach). Data yang digunakan dalam penulisan ini adalah data sekunder, yaitu buku-buku perpustakaan, peraturan perundang-undangan, karya ilmiah, artikel-artikel, serta dokumen yang berkaitan dengan materi penelitian.

\section{HASIL DAN PEMBAHASAN}

\section{Upaya Pemerintah Memberantas Perdagangan}

\section{Manusia terhadap TKI}

Pencegahan tindak pidana perdagangan orang dapat dimulai dengan memperbaiki sistem hukum, mulai dari substansi dan struktur hukum serta budaya hukum yang hidup di masyarakat. Kemudian diimplementasikan dengan proses penegakan hukum yang sesuai dengan aturan yang ada (Prakoso, \& Nurmalinda, 2018). Peran pemerintah dalam upaya memberikan perlindungan dan mengatur penempatan bagi para pekerja migran antara lain mengeluarkan berbagai instrumen hukum mulai dari konsitusi hingga peraturan pelaksananya. Berikut peraturan yang mengatur mengenai perlindungan tenaga kerja migran korban tindak pidana perdagangan manusia. Mayoritas pekerja migran Indonesia menghadapi kondisi kerja paksa, kebanyakan kasus terkait dengan kondisi kerja di negara penerima, seperti upah yang tidak dibayar, kerja paksa, jam kerja tidak teratur, pelecehan seksual dan kekerasan fisik (Rahayu, 2017).

Dalam pembukaan Undang-Undang Dasar Negara Republik Indonesia Tahun 1945 (selanjutnya disebut UUD NRI Tahun 1945) alinea IV, yakni melindungi segenap bangsa dan seluruh tumpah darah Indonesia. menjadi salah satu tujuan negara Indonesia. Perlindungan terhadap rakyat serta pemenuhan hak-hak warga negara jelas menjadi salah satu komponen yang harus dilindungi, selain perlindungan terhadap kedaulatan dan kekayaan alamnya. Pasal 27 ayat (2) UUD NRI Tahun 1945 juga mengatur bahwa tiap-tiap warga negara berhak atas pekerjaan dan penghidupan yang layak bagi kemanusiaan. Arti dan makna dari pentingnya pekerjaan dan penghidupan yang layak jelas tertuang dalam konstitusi. Namun dalam kenyataannya, terbatasnya lowongan pekerjaan di dalam negeri membuat banyak masyarakat yang memilih menjadi TKI di luar negeri. Pasal 28 huruf (D) UUD NRI Tahun 1945 sendiri menyatakan bahwa setiap orang berhak atas pengakuan, jaminan, perlindungan, dan kepastian hukum yang adil serta perlakuan yang 
Jurnal Pembangunan Hukum Indonesia

Volume 2, Nomor 1, Tahun 2020
Program Studi Magister Ilmu Hukum Fakultas Hukum Universitas Diponegoro sama dihadapan hukum. Serta berhak untuk bekerja serta mendapat imbalan dan perlakuan yang adil dan layak dalam hubungan kerja.

Diatur pula dalam berbagai Undang-Undang diantaranya, Undang - Undang No. 13 Tahun 2003 tentang Ketenagakerjaan (selanjutnya disebut UU Ketenagakerjaan). Pasal 31 dan Pasal 32 UU Ketenagakerjaan menjelaskan bahwa sudah menjadi hak TKI untuk mendapatkan, memilih dan pindah tempat kerja sesuai dengan kemampuan, keahlian dan keterampilannya masing-masing. Juga termasuk menerima penghasilan yang layak di dalam atau di luar negeri dengan memperhatikan harkat, martabat, hak asasi dan perlindungan hukumnya. Undang-Undang No. 39 Tahun 2004 Tentang Penempatan dan Perlindungan Tenaga Kerja Indonesia di Luar Negeri (selanjutnya disebut UU PPTKAI LN). UU ini merupakan UU pertama yang secara khusus mengatur berkenaan dengan legalitas pengiriman TKI serta pencegahan dan upaya penanggulangan perdagangan. Namun tidak secara detail mengatur dengan jelas pembagian tugas dan wewenang pemerintah pusat, pemerintah daerah dan swasta secara proposional.

Terdapat pula dalam Undang-Undang No. 21 Tahun 2007 tentang Pemberantasan Tindak Pidana Perdagangan Orang (selanjutnya disebut UU PTPPO). Menurut UU ini, perdagangan orang adalah tindakan perekrutan, pengangkutan, penampungan, pengiriman, pemindahan atau penerimaan seseorang dengan cara kekerasan, penculikan, penyekapan, pemalsuan, penipuan, penyalahgunaan kekuasaan atau posisi rentan, penjeratan utang atau memberi bayaran atau manfaat, sehingga memperoleh persetujuan dari orang yang memegang kendali atas orang lain, baik yang dilakukan di dalam negara maupun antar negara, untuk tujuan eksploitasi atau mengakibatkan orang tereksploitasi. Kebijakan hukum pidana dalam menangani tindak perdagangan orang pada saat ini sudah cukup baik dengan adanya Undang - Undang No. 21 Tahun 2007 tentang Pemberantasan Tindak Pidana Perdagangan Orang. Dimana dalam UU ini mengatur mengenai ancaman pidana bagi pelaku perdagangan orang menganut minimal pidana hingga maksimal, serta korban juga berhak mendapatkan kompensasi dan restitusi serta ganti rugi dari pelaku. UU ini juga memberikan peluang adanya usaha pemerintah untuk memberikan perlindungan bagi korban, saksi maupun pelapor. Disamping itu juga, dikenal pemberatan hukuman pada kasus perdagangan orang sebagaimana dikenal dalam hukum pidana Indonesia. Penegakan hukum pidana saat ini dalam penghadapi perkara TPPO didasarkan pada sejumlah ketentuan perundang-undangan, yaitu UU PTPPO, KUHP, KUHAP dan sejumlah peraturan hukum pelaksanaan pidana (Siswanto, 2013).

Beberapa undang-undang berikut meratifikasi konvensi yang disepakati Indonesia diantaranya, Undang-Undang No. 15 Tahun 2009 tentang Pengesahan Protocol Against the Smuggling of Migrants by Land, Sea and Air, Supplementing The United Nations Convention Against Transnational Organized Crime (Protokol Menentang 
Jurnal Pembangunan Hukum Indonesia

Volume 2, Nomor 1, Tahun 2020
Program Studi Magister Ilmu Hukum Fakultas Hukum Universitas Diponegoro
Penyelundupan Migran Melalui Darat, Laut dan Udara, Melengkapi Konvensi Perserikatan Bangsa-Bangsa Menentang Tindak Pidana Transnasional Yang Terorganisasi). Undang -Undang No. 6 Tahun 2012 tentang Pengesahan International Convention on the Protection of the Rifghts of All Migrant workers and Members of Their Families ( Konvensi Internasional mengenai Perlindungan Hak-Hak Seluruh Pekerja Migran dan Anggota Keluarganya).

Undang-Undang No. 18 Tahun 2017 tentang Pelindungan Pekerja Migran Indonesia dianggap sebagai bukti keseriusan pemerintah terhadap perlindungan tenaga kerja migran. Terdapat banyak kemajuan dalam beberapa aspek, di antaranya adalah aspek perlindungan yang telah mengadopsi Konvensi Internasional tentang Perlindungan Hak-hak Pekerja Migran dan Anggota Keluarganya, yang juga telah diratifikasi oleh Pemerintah Indonesia melalui Undang-Undang No.6 Tahun 2012. Dalam UU baru tersebut masalah rekrutmen calon pekerja migran, pelayanan imigrasi, kesehatan, hingga pelatihan menjadi tanggungjawab pemerintah dan pemerintah daerah, ini merupakan wujud negara hadir dalam perlindungan pekerja migran. Pihak swasta dalam hal ini perusahaan Pelaksana Penempatan Tenaga Kerja Indonesia Swasta (PPTKIS) hanya sebagai marketing penempatan. Amanat Undang-Undang No.18 Tahun 2017 adalah untuk menyusun 11 peraturan pemerintah, 2 peraturan presiden, 12 peraturan menteri, dan 3 peraturan kepala badan dalam jangka waktu 2 tahun. Sebagai peraturan pelaksana ada Peraturan Pemerintah No. 9 Tahun 2008 tentang Tata Cara dan Mekanisme Pelayanan Terpadu bagi Saksi dan/atau Korban Tindak Pidana Perdagangan orang dam Peraturan Presiden No.69 Tahun 2008 tentang Gugus Tugas Pencegahan dan Penanganan Tindak Pidana Perdagangan Orang. Sebagai peraturan pelaksana dari UU TTPO.

Dengan berbagai instrumen hukum diatas, penegakan hukum yang terjadi di lapang masih jauh dari harapan. Hal ini terlihat dari data kepolisian yang menunjukkan penanganan kasus perdagangan orang yang sedikit dibanding kasus itu sendiri. Begitu pula dengan kualitas penegakan hukum sangat tidak signifikan, dimana tidak pernah ada sanksi optimal sesuai aturan termasuk bagi pelaku perdagangan orang yang telah membuat menderita korban sampai meninggal dunia, yang seharusnya dihukum lebih dari 15 atau 20 tahun dan denda lebih dari 2 miliar, namun justru hukuman ringan yang dikenakannya, rata-rata 3-4 tahun yang terberat hanya 8 tahun (Riadi, 2017).

Hukum internasional juga memiliki payung hukum sendiri yang mengatur mengenai perdagangan orang. Tahun 2000 di Italia, PBB merumuskan sebuah protokol untuk mencegah, menindak dan menghukum perdagangan orang, terutama perempuan dan anak (United Nations Protocol to Prevent, Suppress and Punish Trafficking in 2 Persons, Especially Woman and Children) yang disebut dengan Protokol Palermo. Protokol ini dirumuskan untuk memperkuat dan meningkatkan kerjasama internasional untuk mencegah dan 
menanggulangi perdagangan orang, serta sembilan puluh tiga pasal (dibandingkan dengan dua dipromosikan untuk memperbaiki perlindungan bagi korban dan bantuan bagi korban. Dalam Protokol Palermo ini, perdagangan manusia didefinisikan sebagai perekrutan, pengiriman, pemindahan, penampungan, atau penerimaan seseorang, dengan ancaman, atau penggunaan kekerasan, atau bentuk-bentuk pemaksaan lain, penculikan, penipuan, kecurangan, penyalahgunaan kekuasaan atau posisi rentan, memberi atau menerima bayaran atau manfaat untuk memperoleh ijin dari orang yang mempunyai wewenang atas orang lain untuk tujuan eksploitasi (Fadil, 2013). Menurut Migration Research Leaders Syndicate, termasuk dalam perdagangan manusia untuk tujuan eksploitasi di antaranya adalah kerja atau layanan paksa, perbudakan atau praktek-praktek serupa perbudakan, perhambaan, pengambilan organ tubuh dan eksploitasi untuk tujuan seksual. Eksploitasi tenaga kerja itu tidak hanya terjadi di sektor informal tapi juga terdapat di berbagai sektor, misalnya pertanian, kontruksi, pembuatan bata, bengkel dan manufaktur. Sedangkan yang mengatur perlindungan buruh migran ada pada Konvensi PBB 1990 mengenai Perlindungan Hak Semua Pekerja Migran dan Anggota Keluarganya (The International Convention of the Protection of the Rights of All Migrant Workers and Members of Their Families biasa disingkat CMW). Secara khusus, CMW menjelaskan serangkaian hak yang luas bagi para migran, termasuk mereka yang tinggal dan / atau bekerja di luar negeri secara ilegal. CMW mencakup puluh tiga pasal Konvensi ILO 97 dan dua puluh empat pasal Konvensi ILO 143) dan memperluas hak asasi manusia yang mendasar kepada semua pekerja migran, baik yang reguler maupun yang tidak teratur, dengan hak tambahan diakui. CMW didasarkan pada prinsip perlakuan yang sama terhadap migran dan warga negara daripada pada pendekatan "standar minimum", yang menjadi ciri banyak instrumen hukum internasional lainnya.

Pemerintah Indonesia menyadari bahwa upaya memberantas tindak kejahatan perdagangan orang tidak bisa dilakukan sendiri melainkan harus bekerjasama dengan Negara lain yang menjadi tujuan perdagangan orang yang berasal dari Indonesia. Seperti terdapat dalam ketentuan perundangan-udangan diatas yang memberikan kewajiban untuk melaksanakan kerjasama pemberantasan perdagangan manusia dengan Negara lain baik itu secara bilateral, regional, maupun multilateral. Selain itu, upaya bilateral juga terus digalakkan pemerintah guna mengatasi masalah ini, seperti yang telah dilakukan dengan pemerintah Australia, Amerika Serikat, Malaysia, dan Saudi Arabia. Kerja sama bilateral dengan pemerintah Indonesia atau dengan negara - negara yang juga sudah meratifikasi konvensi internasional seperti Konvensi Internasional Mengenai Perlindungan Hak Hak Seluruh Buruh Pekerja Migran dan Anggota Keluarganya serta Konvensi ILO yang sudah memuat unsur perlindungan terhadap tenaga kerja asal Indonesia apabila mengalami masalah hukum di 
negara penerima TKI tersebut. Sebagai contoh perjanjian bilateral antara Pemerintah Indonesia dan Pemerintah Persatuan Emirat Arab (PEA) yang menandatangani Perjanjian Kerja sama Pencegahan Perdagangan Manusia dan Perlindungan bagi Korban Perdagangan Manusia. Kedua negara sepakat untuk bekerjasama memberikan perlindungan, rehabilitasi dan bantuan termasuk repatriasi kepada para korban perdagangan manusia. Dalam lingkup regional negara-negara Asia Tenggara, Melalui Konferensi Tingkat Tinggi (KTT) ke-31 ASEAN di Manila, Filiphina, para pemimpin negara-negara ASEAN telah menyepakati "ASEAN Consensus on the Promotion and Protection of the Rights of Migrant Workers". Sebuah kesepakatan penting dalam upaya meningkatkan perlindungan terhadap pekerja migran dan keluarganya di kawasan ASEAN. Secara garis besar, isi konsensus terkait dengan hak pekerja migran, kewajiban negara pengirim, serta kewajiban negara penerima pekerja migran. Selain pada kerjasama ASEAN, kerjasama bilateral untuk menangani isu ini juga dilakukan oleh Indonesia dan Australia pada tahun 2002 dengan menginisiasi Bali Process Regional Ministerial Conference (Bali Process) yang beranggotakan 42 negara. Dengan meningkatnya arus kejahatan tersebut, Bali Process memiliki peran sebagai forum penyusunan mekanisme kawasan dalam penanggulangan masalah regional yang memerlukan solusi global.

Selain itu, pemerintah melalui Kementerian Tenaga Kerja dan Transmigrasi (selanjutnya disebut
Kemnaker) terus menambah jumlah dan kapasitas diplomatik Atase Ketenagakerjaan(selanjutnya disebut Atnaker) dan staf teknis Ketenagakerjaan untuk bertugas di negara penempatan. Hal ini dilakukan untuk meningkatkan pelayanan dan terhadap pekerja migran Indonesia yang bekerja di luar negeri. Atnaker memiliki tugas dan fungsi yang tidak mudah. Selain melayani, mellindungi dan mengatasi persoalan TKI, atnaker juga harus mengurusi persoalan dan isu ketenagakerjaan lainnya. Selain menjaga citra Indonesia di kancah Internasional, atnaker juga terkait persoalan ketenagakerjaan secara umum. Misalnya informasi pasar kerja (labour market information) dan pelatihan vokasi (vocational training).

Pada 2017 pemerintah Indonesia hanya memiliki atnaker di empat negara yakni Arab Saudi (di Riyadh), Kuwait, Malaysia dan Uni Emirat Arab. Saat ini Kemnaker memiliki sembilan atnaker dan dua staf teknis ketenagakerjaan untuk ditempatkan di 10 negara penempatan TKI. Sembilan ditempatkan di Koraea Selatan, Brunei Darussalam, Qatar, Singapura, Jordania, Arab Saudi, Kuwait, Malaysia dan Uni Emirat Arab, dan dua staf teknis ketenagakerjaan ditempatkan di Hongkong dan Jeddah (Arab Saudi). Selain oleh negara, upaya menangkal tindak kejahatan ini juga dilakukan oleh lembaga nonpemerintah seperti LSM baik lokal, nasional maupun internasional, organisasi-organisasi kemasyarakatan,individu-individu. Peranan organisasi internasional dalam perlindungan buruh migran telah diakui keberhasilannya dalam upaya memecahkan 
berbagai macam persoalan yang dihadapi oleh suatu negara. Peranan organisasi internasional dinilai secara tidak langsung dapat mempengaruhi tingkah laku negara. Hadirnya organisasi internasional memberikan gambaran kebutuhan manusia untuk bekerjasama, dan sebagai sarana untuk menyelesaikan permasalahan yang timbul melalui kerjasama tersebut (Perwira, \& Yani, 2005).

2. Perlindungan Hukum terhadap TKI Korban Perdagangan Manusia.

Pemerintah harus serius dan bekerja keras agar angka perdagangan manusia dapat diturunkan. Namun disisi lain pemerintah juga membuka keran pengiriman buruh migran ke luar negeri, dimana hal ini menjadi peluang atau salah satu faktor penyebab terjadinya perdagangan manusia. Tercatat kurang lebih terdapat 10 Peraturan Perundang-Undangan yang dibuat dari tingkat nasional hingga daerah sebagai political will dari pemerintah untuk mencegah dan menangani permasalahan ini, namun faktanya adanya political will dari pemerintah belum membawa perubahan yang signifikan.

Dalam berbagai studi dan laporan dari sejumlah LSM menyatakan bahwa Indonesia masih merupakan daerah sumber perdagangan orang, disamping juga sebagai negara transit dan negara penerima. Sedikitnya diidentifikasi 10 provinsi di Indonesia yang dijadikan sebagai sumber, 16 provinsi dijadikan sebagai tempat transit, dan sedikitnya 12 provinsi sebagai penerima. Belum ditemukan jumlah yang akurat untuk jumlah perempuan dan anak korban perdagangan orang di
Indonesia. Data yang tersedia beragam dari 74.616 orang hingga 1 juta pertahun. Sekitar 199 orang telah ditangkap dan 5.668 orang yang diduga menjadi korban perdagangan manusia telah dipulangkan ke tanah air (Akbar, 2018). Banyak korban takut melaporkan kejahatan perdagangan manusia kepada petugas negara setempat, karena adanya kemungkinan deportasi dan juga kemungkinan retaliasi dari pelaku (Kidane, 2011).

Permasalahan krusial dalam rangka memberantas tindak pidana perdagangan orang adalah masih ada nya budaya patriarkhi yang memposisikan perempuan tidak setara dengan laki-laki dan masih terbatasnya kesempatan berkarier bagi wanita. Paradigma mengenai kemampuan dan professionalisme perempuan belum dianggap setara dengan laki-laki, wanita masih dianggap sebagai subordinasi dalam keluarga. Dalam banyak kasus masih ada budaya malu atau tabu melaporkan perlakuan kasar dari suami terhadap isteri, anak-anak serta wanita di dalam lingkungannya dan lain sebagainya (Minin, 2011).

Berdasarkan data dari International Organization for Migration (IOM) dan Non Governmental Organization (NGO) anti trafficking, diperkirakan 43\% - 50\% atau sekitar 3-4,5 juta TKI menjadi korban perdagangan manusia. Berdasarkan hasil identifikasi, $90 \%$ dari 3.840 korban trafficking adalah perempuan dan sebanyak $56 \%$ dieksploitasi sebagai pekerja rumah tangga. Human trafficking umumnya terjadi karena tingkat kemiskinan yang tinggi, pengangguran dan sempitnya lapangan 
pekerjaan, serta sulitnya mengenyam pendidikan sehingga lebih mudah bagi para traffickers untuk memancing korban dengan modus untuk menjadi TTKI dan diiming-imingi bayaran yang tinggi serta kehidupan yang lebih baik. Disamping faktor-faktor diatas, faktor budaya serta gaya hidup yang konsumtif akibat arus globalisasi yang tinggi juga menjadi penyebab mudahnya terjadi perekrutan korban oleh traffickers. Korban dikirim ke banyak negara seperti Singapura, Malaysia, Brunei Darussalam, Hongkong, Taiwan, Korea, Jepang, Australia, Timur Tengah, Inggris, hingga negara-negara di Eropa. Mereka diperdagangkan untuk menjadi buruh, dieksploitasi secara seksual, bahkan menjadi korban penjualan organ-organ tubuh. Bisnis ini dapat dengan mudah dilakukan oleh para traffickers akibat banyaknya jalur-jalur transportasi baik darat maupun laut yang kurang penjagaannya dan daerah-daerah tersebut berbatasan langsung dengan negara-negara tetangga seperti Singapura dan Malaysia (Utami, 2017). Sejumlah besar pekerja migran perempuan Indonesia yang menjadi korban perdagangan orang menderita pelecehan dan kekerasan, termasuk pelecehan seksual, kondisi kerja yang buruk, jam kerja yang panjang, serta jeratan hutang (Aronowitz, 2009).

Terkait dengan tenaga kerja, perlindungan hukum diartikan sebagai penjagaan agar tenaga kerja dapat melakukan pekerjaan yang layak bagi kemanusiaan (Bambang, 2013). Upaya memberikan perlindungan kepada para tenaga kerja merupakan satu dari beberapa cara yang harus dilakukan untuk menciptakan kondisi agar para tenaga kerja dapat melaksanakan hak dan kewajibannya dan tentu terciptanya suasana kerja yang harmonis (Soepomo, 2003). Fungsi perlindungan hukum yang dapat diberikan oleh perwakilan RI antara lain menghindarkan atau mengkoreksi praktik-praktik dari negara penempatan yang bersifat diskriminatif terhadap negara dan warga negaranya, memberikan bantuan atau pelayanan kepada warga negara yang melanggar peraturan hukum di luar negeri, dan memberikan perlindungan dan bantuan hukum (Rudi, 2009). Pada dasarnya bentuk-bentuk atau model perlindungan terhadap korban kejahatan dapat diberikan kepada korban tindak pidana perdagangan orang, untuk dapat mendalami bentuk-bentuk atau model perlindungan hukum yang dapat diberikan kepada korban, yaitu sebagai berikut: (1) Pemberian Restitusi dan Kompensasi, (2) Layanan Konseling dan Pelayanan/Bantuan Medis, (3) Bantuan Hukum, (4) Pemberian Informasi (Mansur, \& Gultom, 2007).

International Organization for Migration Indonesia atau IOM Indonesia telah menjadi salah satu aktor dan mitra kunci pemerintahan Indonesia dalam pemberantasan perdagangan manusia. Sebagai bagian dari Program Bantuan bagi Korban, IOM Indonesia menyediakan bantuan pemulangan, pemulihan dan reintegrasi bagi korban dari Indonesia dan asing melalui program "dana bantuan korban". Bantuan reintegrasi termasuk program perawatan kesehatan fisik dan mental, tempat penampungan sementara, konseling keluarga, bantuan pendidikan, 
bantuan penghidupan dan bantuan hukum. Bantuan diberikan melalui mekanisme rujukan bekerjasama dengan lebih dari 80 negara dan non-negara. Antara 2005 hingga 2013, IOM Indonesia membantu lebih dari 6,432 korban perdagangan orang bersama dengan mitra-mitranya.

Selain perlindungan, UU juga memberikan hak-hak kepada korban perdagangan manusia berupa hak kerahasianaan identitas korban, hak untuk mendapatkan perlindungan dari ancaman yang membahayakan diri jiwa dan / atau hartanya. Termasuk juga hak untuk mendapat restitusi, hak untuk memperoleh rehabilitasi, kesehatan, rehabilitasi sosial,pemulangan dan reintegrasi sosial dari pemerintah. Korban yang berada di luar negeri berhak dilindungi dan dipulangkan ke Indonesia atas biaya negara. Sedangkan perlindungan hukum terhadap TKI korban perdagangan pada saat ini lebih mengendepankan pemenuhan hak - hak korban. Seperti mendapatkan bantuan hukum dari pengacara lokal yang ditunjuk oleh duta besar Republik Indonesia di negara penerima TKI, pendampingan oleh psikolog dan rohaniawan, didatangkannya keluarga korban, ganti rugi, serta klaim asuransi.

\section{KESIMPULAN}

Upaya pemerintah memberantas perdagangan manusia terhadap tenaga kerja Indonesia antara lain: mengeluarkan berbagai instrumen hukum mulai dari konsitusi hingga peraturan pelaksananya, melakukan kerjasama baik itu secara bilateral, regional, maupun multilateral dengan negara-negara lain, terutama negara tujuan penempatan TKI. Serta bersama dengan bantuan dari lembaga nonpemerintah seperti LSM baik lokal, nasional maupun internasional, organisasi-organisasi kemasyarakatan, individu-individu untuk selalu meberikan penyuluhan, pelatihan hingga bantuan perlindungan hukum kepada TKI.

Dalam memberikan perlindungan hukum kepada TKI korban perdagangan manusia, pemerintah Indonesia mermberikan restitusi dan kompensasi, layanan konseling dan pelayanan/bantuan medis, bantuan hukum dan pemberian informasi serta menjamin pemenuhan hak-hak TKI korban perdagangan manusia, seperti kerahasian identitas hingga hak untuk mendapatkan rehabilitasi.

\section{DAFTAR PUSTAKA}

\section{BUKU}

Aronowitz, Alexis A. (2009). Human Trafficking, Human Misery: the Global Trade in Human beings. Westpoint Connecticut:: Greenwood Publishing Group

Bambang, J. (2013). Hukum Ketengakerjaan. Bandung: Pustaka Setia Bandung. Dimyati, K. (2010). Teorisasi Hukum; Studi Tentang Perkembangan Pemikiran Hukum Di Indonesia 1945-1990. Yogyakarta: Genta Publishing.

Mansur, Dikdik M. Arief., \& Gultom, Elisatris.(2007). Urgensi Perlindungan Korban Kejahatan Antara Norma dan Realita. Jakarta: Raja Grafindo Persada. 
Nuraeny, H. (2011). Tindak Pidana Perdagangan Orang. Jakarta: Sinar Grafika.

Perwira, Anak Agung B., \& Yani, Yanyan Mochamad. (2005). Pengantar IImu Hubungan Internasional. Bandung: PT Remaja Rosdakarya.

Rahardjo, S. (1986). Hukum dan Masyarakat. Bandung: Angkasa.

Rudi, T. May. (2009). Hukum Internasional 2. Bandung: PT Refika Aditama.

Soepomo, I. (2003). Pengantar Hukum Perburuhan. Jakarta : Djambatan

Shelley, L. (2010). Human Trafficking, A Global Perspective. Cambridge: Cambridge University Press.

\section{J URNAL}

Absor, Muhammad U. (2018). Human Trafficking and the Challenges for Social Development in Indonesia. J urnal Pemikiran Sosiologi, Vol. 5, (No. 1), pp 37-50.

Akbar, D. (2018). Tinjauan Hukum dan Peran Pemerintah dalam Tindak Pidana Perdagangan Orang (TPPO) di Kabupaten Karimun dan Batam. J urnal Selat, Vol. 5, (No. 2), pp. 134-145.

Daniell, Everd Scor Rider., Mulyana, Nandang., \& Wibhawa, Budhi. (2018). Human Trafficking di Nusa Tenggara Timur. Social Work J urnal, Vol. 7, (No. 1), pp.1-129.

Djelantik, S. (2016). Regional Cooperation and Legal Protection to Indonesia Women Migrant
Worker. Indonesian J ournal of International Law, Vol. 14, (No. 1), pp. 82-94.

Fadil, M. (2013). Pengaturan Hukum Internasional tentang Larangan Perdagangan Perempuan Serta Implementasinya di Indonesia. Jurnal Ilmu Hukum Legal Opinion, Vol. 1, ( No. 5), pp. 1-10.

Kidane, W. (2011). Introduction: Understanding Human Trafficking and its Victims. Seattle J ournal for Social J ustice, Vol. 9, (Issue 2), p. 176.

Minin, D. (2011). Strategi Penanganan Trafficking di Indonesia. Kanun J urnal IImu Hukum, Vol. 13, (No. 54), pp. 21-31.

Muflichah, Siti., \& Rahadi, Wasi Bintoro. (2009). Trafficking: Suatu Studi tentang Perdagangan Perempuan dari Aspek Sosial, Budaya dan Ekonomi di Kabupaten Banyumas. Jurnal Dinamika Hukum, Vol. 9, (No. 1), pp 125-134.

Oppong, Steward H. (2012). Human Trafficking Through Organized Crime. International J ournal of Humanities and Social Science, Vol.2, (No. 20), pp. 37-43

Prakoso, Abdul Rahman., \& Nurmalinda, Putri Ayu. (2018). Kebijakan Hukum Terhadap Tindak Pidana Perdagangan Orang. Seminar Nasional Hukum Universitas Negeri Semarang, Vol. 4, (No.1), pp 1-24.

Rahayu, N. (2017). Indonesia Migrant Worker Policies and the Vulnerability of Women Migrant Workers to Becoming Trafficking Victims: an Overview of Recent Legislation. Journal of 
Jurnal Pembangunan Hukum Indonesia

Volume 2, Nomor 1, Tahun 2020
Program Studi Magister IImu Hukum Fakultas Hukum Universitas Diponegoro

Southeast Asian Human Rifgts, Vol. 1 , (No.2),

pp. 159-173

Riadi, W. (2017). Perdagangan Orang Ditinjau dari

Perspektif Pertahanan Negara. J urnal Strategi

Perang Semesta, Vol. 3,( No.2), pp. 13-26.

Siswanto, H. (2013). Telaah Kritis: Kegagalan

Penegakan Hukum Pidana Kejahatan

Perdagangan Orang. Masalah-Masalah

Hukum, Vol. 43,(No. 4), pp. 463-472.

Susetyorini, P. (2010). Perlindungan Tenaga Kerja

Indonesia (TKI) di Luar Negeri oleh Perwakilan

Republik Indonesia. Masalah - Masalah

Hukum, Vol. 39,(No.01), pp. 65-77.

Utami, P. (2017). Upaya Pemerintah Indonesia dalam Mengatasi Human Trafficking di Batam. J ournal IImu Hubungan Internasional, Vol. 5, (No. 4), pp 1257-1272.

Winterdyk, John., \& Reichel, Philip. (2010).

Introduction to Special Issue Human

Traffficking: Issues and Perspectives.

European Journal of Criminology, Vol. 5, (Issue 1), pp.5-10.

Wright, Chris F., \& Clibborn, Stephen. (2019).

Migrant labour and loq-quality work: A persistent relationship. J ournal of Idustrial Relations, Vol. 61, (Issue 2), p 157-175. 